\title{
Agronomic Responses of Cymbopogon schoenanthus L. Spreng., a Sudanese Forage Grass Grown under Compost for a Bio-Ecological Pasture in the Southern Benin
}

\author{
Ezéchiel J-P. A. Mensah, Valentin Kindomihou, Silvère Tovignan, Aliou Saïdou, \\ Davo Simplice Vodouhè, Isaac Aiyelaagbe, and Brice Sinsin
}

\section{ABSTRACT}

Promoting ecological and organic agriculture (including livestock) requires biological resources and alternatives. Cymbopogon schoenanthus is a sudano-sahelian grass species whose crude leaf essential oils, in addition to their antifungal, antimicrobial, antibacterial and acridifuge or acridicide properties, can be an alternative to chemical insecticides in preventing pests and diseases that limit crops productivities. This study tests the agronomic performances of Cymbopogon schoenanthus grown under three doses of compost. Stumps collected from the Park W of Niger were transplanted to the experimental farm of the Faculty of Agronomic Sciences of University of Abomey-Calavi in the Southern Benin. The experimental design was a complete randomized block with treatments $(0$ ton per hectare (i.e., control), 5 tons per hectare and 10 tons per hectare of compost) in four replicates. Plants responses to the compost application throughout traits such as heights, number of tillers per plant, number of flowering tillers and dry aerial biomass production, were analyzed with a one-way ANOVA using STATISTICA 9.0. The results show significant responses of the aerial organs of $C$. schoenanthus to organic fertilization $(p<0.05)$ with the best performance under 5 tons of compost per hectare: height growth in magnitude of $\mathbf{1 2 . 7 2 \%}$, number of tillers multiplied in $\mathbf{1 4 6 . 0 6 \%}$ and aerial dry biomass in $\mathbf{1 7 8 . 3 2 \%}$. However, fertilization did not influence flowers appearance. Further studies are required for assessing foliar, nutritional quality and essential oil responses to the compost application in order to sustainably promote small ruminants' organic production.

Keywords: Cymbopogon schoenanthus, compost, agronomic parameters, Southern Benin.

\section{INTRODUCTION}

Public opinion tends to view organic agriculture as irrelevant to its potential for food security. Yet organic agriculture, as a comprehensive system, improves the productivity and well-being of communities, including ground organisms, vegetation, livestock, and people [1]. Its primary goal is the development of sustainable and environmentally harmonized farms. Like organic agriculture, organic livestock farming (beekeeping, animal husbandry, poultry farming...) is still developing, but under foreign subsidies (French Embassy, GIZ, Biovision Africa
Published Online: June 09, 2021

ISSN: $2684-5199$

DOI: 10.24018 /ejbio.2021.2.3.187

Ezéchiel J.P.A. Mensah*

Ph.D. Student, Laboratory of Applied Ecology (LEA), Faculty of Agronomic Sciences (FSA), University of Abomey-Calavi (UAC), Calavi, Republic of Benin.

(e-mail: mensahjpa ${ }^{@}$ gmail.com)

Valentin Kindomihou

LEA/FSA/UAC, Calavi, Republic of Benin.

(e-mail: kindomihou@ ${ }^{@ m a i l . c o m) ~}$

Silvère Tovignan

Department of Agricultural Economy, Faculty of Agronomy, University of Parakou, Republic of Benin.

Aliou Saïdou

Research Unit of soils and crops integrated Management (ISCM) FSA/UAC, Calavi, Republic of Benin. Davo Simplice Vodouhè

Beninese organization for Promotion of Organic Agriculture (OBEPAB), and West African Network for Ecological and Organic Agriculture (PABE-Benin), Calavi, Republic of Benin.

Isaac Aiyelaagbe

Horticulture Department, Federal University of Agriculture of Abeokuta, Abeokuta, Ogun State, Nigeria.

Brice Sinsin

LEA/FSA/UAC, Republic of Benin.

*Corresponding Author

Trust...) in Tropics. Its general principles as adapted from the Canadian Organic Standards [2] are: (i) Protecting environment, minimizing soil degradation and erosion, reducing pollution, optimizing organic productivity, and promoting good health; (ii) Maintaining long-term soil fertility by promoting conditions conducive to biological activity; (iii) Maintaining ecological diversity in the ecosystem; (iv) Recycling materials and resources on farm; (v) Caring livestock to promote their health and meeting their behavioral needs; (vi) Preparing organic products paying attention to processing and handling methods, to maintain the biological integrity and essential qualities of 
the product; and (vii) Relying on renewable resources in locally organized farming systems.

Organic herbivore meat production systems rely on the provision of a globally balanced diet of energy, protein and vitamins, mainly from grazed and conserved forages. Specifically, the organic forage crops production, as a lever, is a farming method which combines cultural, biological, and mechanical techniques for strengthening the resources cycle, maintaining the ecological balance, and preserving the biodiversity.

In this context, disease and insect control involves preventive methods such as crop rotation, genetic improvement, and the use of resistant varieties [3]. On the organic farm, integrated soil conservation and pest and weed management are important tools. Pesticides approved for use in organic agriculture are "natural" pesticides or other pest control products listed in the Permitted Substances List (PSL) of the organic production standards. The PSL determines which substances can be used as pesticides in organic agriculture [2].

The use of chemical pesticides is confronted with the development of pest resistance in Tropics [4], [5]. In order to ensure the balance of aquatic, terrestrial ecosystems and human health, the use of essential oils with proven antibacterial and antimicrobial properties, is experiencing renewed interest. But the production of "pesticidal plants" is still not very effective since most are not cultivated [5]. Facing the consumer desire to access $100 \%$ natural products that are healthy and effective [4], natural production is proving to be important for the manufacture of essential oils. Cymbopogon schoenanthus L. Spreng. (Poaceae) is a tropical aromatic spice, forage, medicinal and stock biopesticide [6]-[11]. Its essential oil contains biocidal piperitone and repellent on the aphid stage 4 adult apterans of Aphis gossypii, a cotton pest [8], [12]-[14]. It shows a promising management of Plutella xylostella, cabbage moth [15]. Its mixture with Neem oil serves as an antiinflammatory inhibiting the growth of adult $P$. xylostella [16], or as a raw material to the biopesticide industry [15], [16]. Moreover, C. schoenanthus is also a consumed and well-fed Sudanese forage plant [11], [17], a perennial grass species from Andropogoneae tribe, growing in dense compact clumps at its base [18]. Benin Republic belongs to the Western Africa which savannas are globally marked with poor agricultural soils [18]. Therefore, organic fertilization should be the best alternative for pasture productivity. In this context, the use of irrigation and fertilization is essential for improving the biological and agronomic performances of organic pastures as previously demonstrated with Loxodera ledermannii [19].

The present study examines, agronomic performances of C. schoenanthus under organic growing conditions in view of its domestication in the context of promoting organic small ruminants farming in Benin.

Moreover, the ruminant farming in Tropics has been viewed as an agro-ecological activity [20], [21]: (i) firstly, because it is highly intensive in ecological knowledge, particularly on savannah ecosystems, and it is an art of natural resource management (pastures, water, forests); (ii) secondly, because it contributes strongly to the soil fertility improvement. It thus leads to the implementation of sustainable and autonomous agricultural systems based on low input use. Therefore, what would be the features in organic production conditions?

Our choice of using the compost is based on the principle of "Feed the soil to feed the plant", which is fundamental in Organic Agriculture. Indeed, adding compost was found increasing soil fertility and organic matter cycle autonomy [22], while its contribution to the pasture or meadows favors the soil biological activity, sanitizes the manure (destroying pathogens and weed seeds by composting), and reduces its volume and thus the doses to be spread [23], [24]. Compost has advantage of not affecting the grass palatability [25], [26], which allows quickly grazing after spreading. Moreover, the compost amended meadows are less fragile to drought and excess water [11], [27]-[29].

\section{MATERIALS AND METHODS}

\section{A. Description of the Experimental Site}

The experiment was conducted on the experimental garden of the Faculty of Agronomic Sciences, University of Abomey-Calavi $\left(06^{\circ} 44^{\prime} 07.9^{\prime \prime} \quad\right.$ North latitude and $002^{\circ} 08^{\prime} 16.8^{\prime \prime}$ East longitude), at $15 \mathrm{~km}$ North along the National Inter-State Road 2 in the Abomey-Calavi District. The climate is Subequatorial marked by two rainy seasons alternating two dry seasons. The long rainy season covers mid-March to end-July and the short season from midSeptember to mid-November. The long dry season covers mid-November to mid-March and the short season from August to mid-September. Annual values of rainfall, temperature, and relative humidity from 2010 to 2014 averaged respectively $1440 \mathrm{~mm}, 28{ }^{\circ} \mathrm{C}$ and $80 \%$. The trials were firstly conducted from mid-August 2013 to mid-March 2014 and repeated the same period 2014-2015.

The physicochemical characteristics of the experimental site are summarized in Table I.

\begin{tabular}{ccc} 
TABLE I: SOIL CHARACTERISTICS & \\
& $0-2 \mathrm{~mm}$ & 10.4 \\
& $2-20 \mathrm{~mm}$ & 2.7 \\
& $20-50 \mathrm{~mm}$ & 1.9 \\
Granulometry $\%)$ & $50-200 \mathrm{~mm}$ & 19.7 \\
& $200-2000 \mathrm{~mm}$ & 65.2 \\
\hline Chemical characteristics & Contents \\
pHwater & 5.85 \\
pHKcl & 0.10 \\
N total $(\%)$ & 0.11 \\
O total $(\%)$ & 0.96 \\
CM $(\%)$ & 1.66 \\
P (ppm) & 9.11 \\
CEC (meq/100g) & 2.54 \\
Ca++ (meq/100g) & 9.00 \\
$\mathrm{Mg}++(\mathrm{meq} / 100 \mathrm{~g})$ & 3.07 \\
$\mathrm{~K}+(\mathrm{meq} / 100 \mathrm{~g})$ & 1.06 \\
$\mathrm{Na}+(\mathrm{meq} / 100 \mathrm{~g})$ & 0.82 \\
Sum of bases & & 0.74 \\
\hline
\end{tabular}

$\mathrm{N}$ total: total nitrogen; $\mathrm{C}$ total: Carbon total; $\mathrm{OM}$ : organic matter; $\mathrm{C} / \mathrm{N}$ : Ratio carbon/nitrogen; Phosphorous; CEC: exchangeable cation capacity; $\mathrm{Ca++}$ : Calcium; $\mathrm{Mg}^{++}$: Magnesium (cation); $\mathrm{K}^{+}$: Potassium (cation), $\mathrm{Na}^{+}$: Sodium (cation); Source: Kindomihou et al. [30].

\section{B. Material}

Cymbopogon schoenanthus strains were collected from the W Park of Niger and transplanted to the Botanical 
Garden of the UAC in 2011. The fertilizing material used is the compost produced in the Market Garden Centre of Houeyiho in Cotonou (Benin). The compost is made from household waste, with a yield of $65.67 \%$. Characteristics of this compost (Table I) results in a $\mathrm{C} / \mathrm{N}$ ratio of $11.69 \%$ and a total phosphorus rate of $0.62 \%$. The humus in the compost has a high CEC and binds mineral nutrient ions such as $\mathrm{K}^{+}$ and $\mathrm{Ca}^{2+}$ cations and phosphates in order to make them available to plants for their growth and development. The physico-chemical composition of the compost used meets international standards for mature compost quality [31].

\section{Methods}

The experimental design is a 3 -fold repeated randomized completed randomized blocs that highlights one species, i.e., Cymbopogon schoenanthus and 3 compost treatments in 3 doses (5 tons of compost per hectare, 10 tons per hectare compost, and 0 ton of compost (absolute control)). A total of 9 beds of $1.5 \mathrm{~m} \times 2 \mathrm{~m}$, one bed per treatment, were installed in a BAC system. 24 stumps were installed per bed with a spacing of $40 \mathrm{~cm}$ between lines and stumps. Fertilizers are applied two weeks after the installation of the plants. Compost doses are applied to each stump according to the doses defined per stump.

\section{Statistical Analysis}

Mean values and standard deviations of the raw data were calculated in Excel software. A one-way Analysis of variance was performed to test agronomic responses to the compost application followed by the post hoc test based on the smallest significant difference at the 5\% threshold using STATISTICA 9.0. Magnitudes assessing the compost effect were calculated as follow:

$$
\Delta v=\frac{(\overline{x l}-\overline{x o})}{\overline{x o}} \times 100
$$

$\Delta v=$ magnitude in $\%, \overline{\mathrm{xi}}=$ average value of a treatment $\mathrm{i}$; $\overline{\mathrm{xO}}=$ average value of the control treatment.

\section{RESULTS}

Table II shows the mean values of agronomic parameters of $C$. schoenanthus along with the 1-way ANOVA result.

TABLE II: EFFECT OF COMPOST ON RECOVERY RATE, NUMBER OF TILLERS AND NUMBER OF FLOWERING TILLERS

\begin{tabular}{cccc}
\hline Treatment & Regrowth rate & $\begin{array}{c}\text { Number of } \\
\text { tillers }\end{array}$ & $\begin{array}{c}\text { Number of } \\
\text { fertile tillers }\end{array}$ \\
\hline $\mathrm{TC}_{60}$ & $45.83 \pm 8.33 \mathrm{a}$ & $112.94 \pm 7.49 \mathrm{a}$ & $3.34 \pm 0.23 \mathrm{a}$ \\
$\mathrm{TC}_{120}$ & $50.00 \pm 7.22 \mathrm{a}$ & $92.39 \pm 3.61 \mathrm{~b}$ & $2.39 \pm 0.17 \mathrm{a}$ \\
$\mathrm{T}_{0}$ & $29.17 \pm 8.33 \mathrm{~b}$ & $45.90 \pm 4.77 \mathrm{c}$ & $2.33 \pm 1.00 \mathrm{a}$ \\
\hline $\mathrm{F}(2,6)$ & 5.73 & 115.49 & 2.67 \\
$\mathrm{P}$ & $*$ & $* * *$ & $\mathrm{~ns}$ \\
$\mathrm{R}^{2}$ & 0.54 & 0.96 & 0.29 \\
\hline$* \mathrm{p}<0.05 ; * * *: \mathrm{p}<0.001 ;$ ns: non-significant; $\mathrm{a}, \mathrm{b}, \mathrm{c}:$ homogenous groups at \\
$5 \%$.
\end{tabular}

Table II indicates that compost fertilization significantly affects the recovery rate of stumps $(\mathrm{p}<0.05)$ and tillering ( $<<0.001$ ), while not the flowering of $C$. schoenanthus.

\section{A. Recovery Rate}

Stumps grown under compost showed the highest recovery rates (from $45.83 \pm 8.33$ to $50.00 \pm 7.22$ ). In contrast, those grown without fertilization gave the lowest recovery rates $(29.17 \pm 8.33)$. Thus, fertilization improved the stumps recovery rate from $57.11 \%$ to $71.41 \%$.

\section{B. Number of Tillers}

C. schoenanthus strains grown without compost showed the lowest average number of tillers per clump $(45.90 \pm 4.77$ tillers) while those grown under compost showed the highest values. The dose of $60 \mathrm{~g}$ per plant gave the highest average number of tillers (112.94 \pm 7.49 tillers). This dose increases the number of tillers per clump in magnitude of $146.06 \%$ compared to $101.29 \%$ obtained under $120 \mathrm{~g}$ per plant.

\section{Total Height and Dry Biomass}

Fig. 1 and 2, showed that the doses of applied compost significantly influenced the growth either in height of the clumps $(\mathrm{p}<0.01)$ or in the aerial biomass production $(\mathrm{p}<0.001)$. C. schoenanthus strains grown with $60 \mathrm{~g}$ per plant showed the highest value of heights $(148.99 \pm 5.07 \mathrm{~cm}$; Fig. 1) while both the controls and strains grown with 120 $\mathrm{g} /$ plant showed the lowest values $(132.17 \pm 1.72 \mathrm{~cm}$ to $132.89 \pm 4.67 \mathrm{~cm}$; Fig. 1). The dose of $60 \mathrm{~g}$ per plant appeared to promote the height in magnitude of $12.72 \%$.

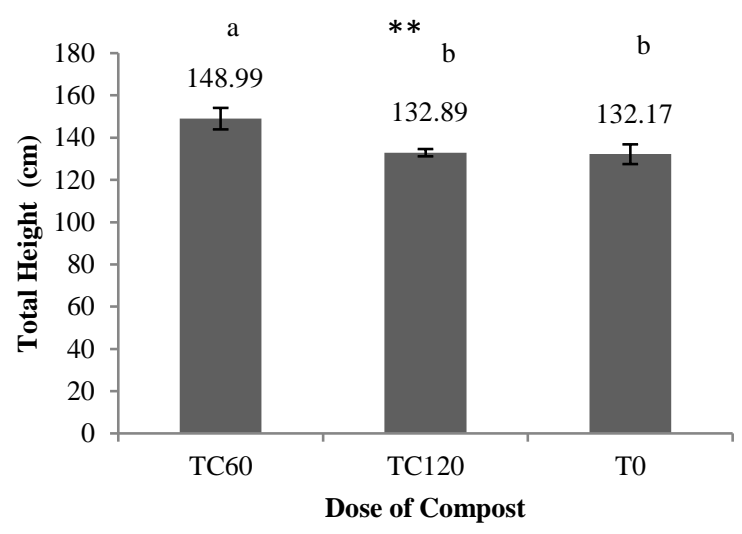

Fig. 1. Effect of compost on total stump height.

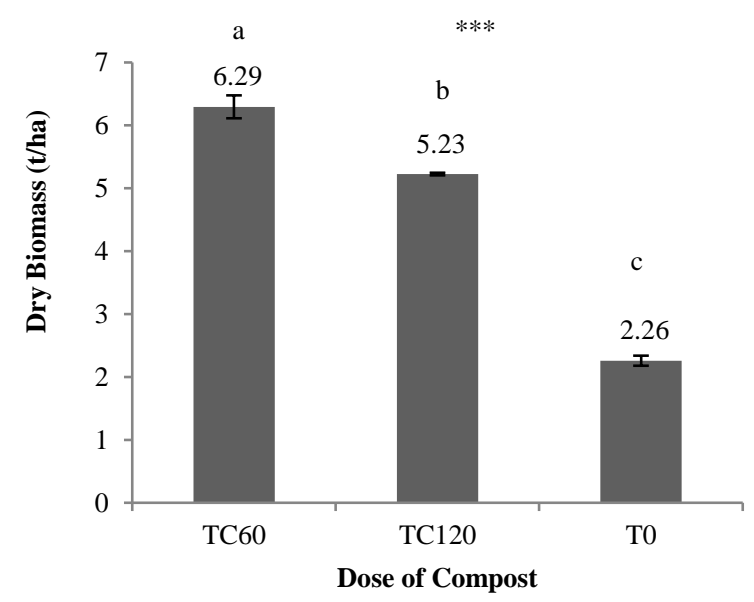

Fig. 2. Effect of compost on biomass production.

Dry biomass yield from plants grown under $60 \mathrm{~g}$ per plant differed significantly from that obtained from materials grown under $120 \mathrm{~g}$ per plant, the latter being lower 
(5.23 \pm 0.02 tons per ha versus $6.29 \pm 0.18$ tons per ha; Fig. 2) These doses significantly increased dry biomass, in respective magnitudes of $178.32 \%$ (under $60 \mathrm{~g}$ per plant) and $131.42 \%$ (under $120 \mathrm{~g}$ per plant).

\section{DISCUSSION}

This study aimed to investigate the $C$. schoenanthus agronomic responses to organic fertilization. For this purpose, two doses of compost (60 g per plant i.e., 5 tons per ha; and $120 \mathrm{~g}$ per plant i.e., 10 tons per ha) with a control (without compost) were applied to C. schoenanthus strains in a complete randomized bloc's design. Stump shattering rate, total clump height, number of tillers per stump, number of flowering tillers, and dry biomass were submitted to a one-way ANOVA. Generally, organic fertilization influenced different agronomic traits except the number of flowering tillers. The strains grown under 5 tons per ha showed the best agronomic performances while the controls had the poorest performance.

Overall, previous studies conducted on the effects of fertilization (organic or mineral) on agronomic parameters of Cymbopogon plants as well as different other plants species mentioned the control treatments giving the poorest performances [8], [32]-[35]. Soil poverty is indicated as the reason for these different results [32]. These results suggest the need for fertilization to achieve good yields on these soils. Indeed, Aken'over \& Chheda [36] proved that monospecific grassland cropping requires fertilization. As stated by Lompo [37], organic fertilization increases cation exchange capacity and therefore quantitative available nutrients, mainly $\mathrm{N}, \mathrm{P}$ and $\mathrm{K}$ in the soil, which are involved in plant growth and development. The low level or absence of these nutrients may reduce yields which are known to be greatly influenced by nitrogen.

The strains grown without fertilization reached $132.17 \mathrm{~cm}$ in height while they do not exceed $120 \mathrm{~cm}$ in natural environment [38].

Our results showed that the dose of 5 tons of compost per hectare induced the best values for height growth (12.72\%), dry biomass (178.32\%) and number of tillers (146.06\%). These results showed that the soil amended with $\mathrm{N}, \mathrm{K}$, and $\mathrm{P}$ from the compost, allowed the $C$. schoenanthus plants to meet their nutrients requirements. Indeed, nitrogenous fertilizer was found increasing Dry Mass yield of Andropogon gayanus Kunth in Burkina Faso [39]. Organic fertilization would increase soil organic matter, maintain the $\mathrm{CEC}$, and limit the exchangeable aluminum rate through complexion process [40]. This efficiency of organic fertilization would also be a matter of water supply during the trial, because during the experiment, the plants were watered morning and evening during the first three years. Accordingly, there is a positive interaction between organic fertilization and irrigation [41]. For these authors, the irrigation increases the compost effectiveness. Consistently, Obulbiga [39] indicated that the effectiveness of positive response of Andropogon gayanus to fertilization like any rain fed crop is closely linked to climatic hazards, especially the rainfall spatio-temporal distribution. The biomass yield increases in response to fertilization, and the plant appears to require more water, which weakens their ability to tolerate the drought. However, it appeared that agronomic performance declined below the application of 10 tons of compost per hectare. This result is consistent with Ballot et al. [35] who showed that increasing dose of fertilizer negatively influences height growth and biomass yield. Indeed, Mitscherlich's law states that increased yields obtained by applying increasing doses of a fertilizer are smaller and smaller as the doses applied increase [42]. Tendonkeng et al. [43] also observed a decrease in the height and diameter of $B$. ruziziensis following the application of high doses of urea. According to these authors, the responsive decrease accuses the root environment and the hydro-mineral nutrition, as previously stated by Morot-Gaudry's [44] when excessive nitrogen supply acidifies plant roots medium and disturb their hydromineral nutrition.

Our results therefore indicate the rate of 5 tons of compost per hectare for organic production of $C$. schoenanthus. This corroborated two previous findings from Abeokuta (Nigeria) in vegetable crop production [33], [34]. However, the best numbers of tillers and dry biomass were provided by a species from same genus i.e., Cymbopogon citratus with the rate of 10 tons of manure per hectare [32].

\section{CONCLUSION}

The organic livestock farming development is indeed possible in the Tropics, and the organic fodder production is an important tool to achieve this goal which is already shared by a number of policies. This study highlighted the rate of compost favoring organic production of Cymbopogon schoenanthus. The dose of $60 \mathrm{~g}$ per plant highly affected agronomic traits. Definitively, $C$. schoenanthus is sensitive to organic fertilization, showing the best performances in our subequatorial field cropping, i.e., the rate of stump sprouting from $57.11 \%$ to $71.41 \%$, the average number of tillers from 45.90 to 112.94 tillers, the highest average height growth i.e., $148.99 \mathrm{~cm}$ and the highest average above-ground dry biomass production i.e., 6.29 tons per ha. This dose which corresponded to 5 tons of compost per hectare, offering the best values and magnitudes for the growth appeared to be effective at organic forage production: Height growth in magnitude of $12.72 \%$, number of tillers in magnitude of $146.06 \%$ and aerial dry biomass in magnitude of $178.32 \%$. Optimal rates of compost for the best biomass and essential oil yields and socio-economic benefits of $C$. schoenanthus cultivation would be relevant. Further studies are also required on foliar nutritional quality and essential oil responses to the compost application in order to sustainably promote small ruminants' organic production in Tropics.

\section{ACKNOWLEDGMENTS}

The Laboratory of Applied Ecology of Professor Brice Sinsin is gratefully acknowledged for school bursary to Ezechiel J-P. A. Mensah (E.J-P.A.M.). In addition, E.J.P.A.M. would like to thank the West African Network for Organic Agriculture Research and Training (WANOARTEU, Cambridge), the West African Network for Ecological 
and Organic Agriculture (PABE-Benin), and Biovision Africa Trust (BvAT- Nairobi, Kenya) for partially supported field research on Forage and Livestock Production in Benin. Appolinaire Effio (MSc) of the Laboratory of Animal Production (FSA-UAC, Benin Republic) helped in data collection. Thanks to Professor Romain Glèlè Kakaï for having targeted the experimental device and validated the data treatments approaches. Moreover, we commend the Heads of African Union State and Government for Resolution Doc. EX.CL/631 (XVIII) which favors the Ecological and Organic Agriculture promotion for its potentials to the Food Security, Rural Poverty Reduction and Resilience to the Climate Change. We thank the African Union Commission for facilitating and supporting the establishment of Ecological and Organic Agriculture Initiative aiming at integrating Principles and values of Ecological and Organic Agriculture into Agricultural development Policies and Programs of African Countries. Our gratitude also goes to the main Technical and Financial Partners, notably the Swiss Development Cooperation (SDC), FiBL, ProCAD/World Bank, Biovision, Helvetas Intercooperation, AfroNet, FARA, OBEPAB and the Swedish Society for Nature Conservation (SSCN) for their financial support for the initiative implementation.

\section{REFERENCES}

[1] Reeve, J.R., Hoagland, L.A., Villalba, J.J., Carr, P.M., Atucha, A., Cambardella, C., Davis, D.R. and Delate, K. "Organic farming, soil health, and food quality: Considering possible links." In: Donald L Sparks, editors: Advances in Agronomy, vol. 137, Chennai: Academic Press; pp. 319- 368, 2016.

[2] Organic Federation of Canada (OFC). "Organic principles and management standards". 2020. www.organicfederation.ca.

[3] Barzman, M., Bàrberi, P., Birch, A.N.E., Boonekamp, P., DachbrodtSaaydeh, S., Graf, B., Hommel, B., Jensen, J.E., Kiss, J., Kudsk, P., Lamichhane, J.R., Messéan, A., Moonen, A.-C., Ratnadass, A., Ricci, P., Sarah, J.-L. and Sattin, M. "Eight principles of integrated pest management". Agronomy and Sustainable Development, vol. 35, pp. 1199-1215, 2015. DOI 10.1007/s13593-015-0327-9.

[4] Hay, M.Y.O.M. "La complexité des simples-caractérisations chimique et biologique de combinaisons hydrolats-huiles essentielles et huiles essentielles-huiles essentielles Pour l'objectivation d'effets conservateurs de produits Phytothérapeutiques". Thèse doctorat, Université de Toulouse, France, 196 p, 2015.

[5] Yarou, B.B.P.S., Komlan, F.A., Mensah, A., Alabi, T., Verheggen, F. and Francis, F. "Plantes pesticides et protection des cultures maraichères en Afrique de l'Ouest (synthèse bibliographique)" Biotechnologie Agronomie Société Environnement, vol. 21, issue 4, pp. 288-304, 2017.

[6] Abdalla Musa, H.A., Ahmed, E.E.A., Mohamed Osman, G.A., Ali, H.A. and Ludwig-Müller, J. "Microbial load and phytochemicals stability of camel hay (Cymbopogon schoenanthus L) leaves as affected by gamma irradiation". Agriculture and Biology Journal of North America, vol. 1, issue 4, pp. 662-670, 2010.

[7] Khadri, A., Serralheiro, M.L.M., Nk6ogueira, J.M.F., Neffati, M. and Smiti, S. "Antioxidant and anti acetylcholinesterase activities of essential oils from Cymbopogon schoenanthus L. Spreng. Determination of chemical composition by GC-mass spectrometry and 13C NMR". Food Chemistry, vol. 109, pp. 630-637, 2008.

[8] Khadri, A., Neffati, M., Smiti, S., Manuel, J., Nogueira, F., Eduarda, M. and Araújo, M. "Influence of salt stress on essential oil yield and composition of lemon grass (Cymbopogon schoenanthus L. Spreng. ssp. Laniger (Hook) Maire et Weil)." Journal of Natural Product Research, vol. 25, issue 2, pp. 108-117, 2011.

[9] Cheel, J., Theoduloz, C., Rodriquez, J. and Shemeda-Hirshmann, G. "Free radical scavengers and antioxidant from lemon grass (Cymbopogan citratus)". Journal of Agricultural and Food Chemistry, vol. 53, pp. 2511-2517, 2005.

[10] Koba, K., Sanda, K., Raynaud, C., Nenonene, Y.A. and Millet, J. "Activités antimicrobiennes d'huiles essentielles de trois
Cymbopogon sp. africains vis-à-vis des germes pathogènes d'animaux de compagnie." Annales de Médecine Vétérinaire, vol. 148, pp. 202206, 2004

[11] Kindomihou V.M. "Introductory Chapter: Milestones in Grasses and Grassland Research", Grasses and Grassland Aspects, Valentin Missiakô Kindomihou, Book Chapter IntechOpen, pp. 1-30, 2020. DOI: $10.5772 /$ intechopen.90770.

[12] Ketoh, G.K., Koumaglo, H.K. and Glitho, I.A. "Inhibition of Callosobruchus maculatus (F.) (Coleoptera: Bruchidae) development with essential oil extracted from Cymbopogon schoenanthus $\mathrm{L}$. Spreng. (Poaceae), and the wasp Dinarmus basalis (Rondani) (Hymenoptera: Pteromalidae)". Journal of Stored Products Research, vol. 4, pp. 363-371, 2005.

[13] Ketoh, G.K., Koumaglo, H.K., Glitho, I.A. and Huignard, J. "Comparative effects of Cymbopogon schoenanthus essential oil and piperitone on Callosobruchus maculatus development". Fitoterapia, vol. 77, pp. 506-510, 2006

[14] Bokobana, E.M., Koba, K., Poutouli, W.P., Akantetou, P.K., Nadio, N.A., Laba, B., Tozoou, P., Raynaud, C. and Sanda, K. "Evaluation du potentiel insecticide et répulsif de l'huile essentielle de Cymbopogon schoenanthus (1.) Spreng. sur Aphis gossypii glover (Homoptera: Aphididae), ravageur du cotonnier au Togo". REV. CAMES, vol. 2, issue 2, pp. 48-55, 2014.

[15] Laba, B., Nenonéné, A.Y., Adjrah, Y., Koba, K. and Poutouli, W. "Efficacy of Cymbopogon schoenanthus L. Spreng (Poaceae) extracts on diamondback moth damaging cabbage". Journal of Biofertilizers and Biopesticides, vol. 3, issue 3, pp. 119, 2012. doi:10.4172/2155-6202.1000119.

[16] Kolani, L., Sanda, K., Agboka, K., Mawussi, G., Koba, K. and Djouaka, R. "Investigation of insecticidal activity of blend of essential oil of Cymbopogon schoenanthus and neem oil on Plutella xylostella (Lepidoptera: Plutellidae)". Journal of Essential Oil Bearing Plants, vol. 19, issue 6, pp. 1478-1486, 2016

[17] Diallo, M.S. "Biologie et écologie de Cymbopogon schoenanthus (L.) Spreng dans la zone soudanienne du Burkina Faso. Cas de Bondoukuy (Province du Mouhoun)". Mémoire de DEA, Université de Ouagadougou, 113 p. 1995.

[18] Sinsin, B. "Individualisation et hiérarchisation des phytocénoses soudaniennes du Nord-Bénin”. Belgian Journal of Botany, vol. 127, issue 1 , pp. $87-103,1994$

[19] Kindomihou, V., Mensah, J.-P. A. E., Glèlè-Kakaï, R., Effio, A., Saïdou, A., Holou, R., Vodouhe, D.S., Aiyelaagbe, I., Harris, P. and Sinsin, B. "Organic Forage Production: Responses of Loxodera ledermannii grown under the compost application in Subequatorial Benin". Annales des Sciences Agronomiques, vol. 23, issue 1, pp. 43$52,2019$.

[20] Altieri, M.A. "Agroecology: The Science of Sustainable Agriculture" Boulder, Westview Press, 1995.

[21] Vall, E., Diallo, M.A., Vigne, M., Bénégabou, I., Vayssières, J., Ba, A., Dongmo A.L. et Blanchard, M. "Les facettes agroécologiques de l'élevage des ruminants en Afrique de l'Ouest et du Centre". Grain de Sel, n63-66, pp. 1-5, 2016.

[22] Ye, L., Zhao, X., Bao, E., Li, J., Zou, Z. and Cao, K. "Bio-organic fertilizer with reduced rates of chemical fertilization improves soil fertility and enhances tomato yield and quality". Scientific Reports, vol. 10, issue 177, pp. 1-11, 2020. https://doi.org/10.1038/s41598019-56954-2.

[23] Diacono, M. and Montemurro, F. "Long-term effects of organic amendments on soil fertility". A review. Agronomy for Sustainable Development, vol. 30, issue 2, pp: 401-422, 2010.

[24] Zhao, Y.-N., He, X.-H., Huang, X.-C., Zhang Y.-Q. and Shi X.-J. "Increasing soil organic matter enhances inherent soil productivity while offsetting fertilization effect under a Rice cropping system". Sustainability, vol. 8, issue 879, pp. 1-12, 2016 , doi:10.3390/su8090879.

[25] Baumont, R. "Palatability and feeding behaviour in ruminants. A review". Annales de Zootechnie, INRA/EDP Sciences, vol. 45, issue 5, pp. 385-400. 1996.

[26] McRoberts, K.C., Ketterings, Q.M., Parsons, D., Hai, T.T., Quan, N.H., Ba, N.X., Nicholson, C.F. and Cherney D.J.R. "Impact of forage fertilization with urea and composted cattle manure on soil fertility in sandy soils of South-Central Vietnam". International Journal of Agronomy, Article ID 4709024, pp. 1-15, 2016. Hindawi Publishing Corporation. http://dx.doi.org/10.1155/2016/4709024.

[27] Sundberg, C. and Navia, R. "Is there still a role for composting?" Waste Management Resources, vol. 32, 459-460, 2014.

[28] Mertenat, A., Diener, S. and Zurbrügg, C. "Black Soldier Fly biowaste treatment-Assessment of global warming potential". Waste Management, vol. 84, pp. 173-181, 2019. 
[29] Ayilara, M.S., Olanrewaju, O.S., Babalola, O.O., and Odeyemi, O. "Waste management through composting: challenges and potentials". Sustainability, vol. 12, issue 4456, pp. 1-23, 2020, doi:10.3390/su12114456.

[30] Kindomihou, V.M., Oumorou, M., Mensah, G.A. and Sinsin, B.A. "Morphological traits and germination of Loxodera ledermannii (Pilger) W.D. Clayton ex Launert caryopses in Southern - Benin". Bulletin de la Recherche Agronomique du Bénin, vol. 65, pp. 37-43, 2009.

[31] Seal, A., Datta, A., Saha, S., Chatterjee, A. K., Barik, A. K., Bhattacharya, S., Levin, Y., Nain, A.S., Asthana, A. and Bera, R. "Soil microbial rejuvenation through soil resource recycling as a part of sustainable management programme: A case study from Lakhipara Tea Estate, Dooars, West Bengal, India Research \& Reviews", Journal of Agricultural Science and Technology, pp. 18-34, 2016.

[32] Tougma, W.S.R. Effets de la fertilisation organique et minérale sur la production en biomasse et en huile essentielle de la citronnelle (Cymbopogon citratus (D.C) Stapf) dans la région des Cascades (Ouest du Burkina Faso). Mémoire d'ingénieur de développement rural, Université Polytechnique de Bobo-Dioulasso, Burkina Faso. 60 p, 2006.

[33] Akanbi, W.B. "Effect of Tithonia compost on the growth and fruit yield of bell pepper (Capsicum frutescens) in south Guinea Savanna zone of Nigeria". Proceedings of the $1^{\text {st }}$ West African Summit and $4^{\text {th }}$ National Conference on Organic Agriculture, 17-21 November 2008, pp. 115-125, 2008.

[34] Adedokun, T.A. and Aiyelaagbe, I.O.O. "Response of greenhouse grown cucumber to compost." Proceedings of the $1^{\text {st }}$ west African Summit and $4^{\text {th }}$ National Conference on Organic Agriculture, 17-21 November 2008, pp. 209-212, 2008.

[35] Ballot, C.S.A., Semballa, S., Atakpama, W., Yangakola, T.M., BoMbi, A.D., Blavet, D., Zinga, I., Wala, K., Batawila, K. and Akpagana, K. "Effet de fumures minérales sur le rendement et la qualité organoleptique du manioc (Manihot Esculenta Crantz) dans la zone de savane au Centre-Sud de Centrafrique". European Scientific Journal, vol 12, issue 6, pp. 185-206, 2016. doi: 10.19044/esj.2016.v12n6p185.

[36] Aken'over, M.E. and Chheda, H.R. "Effect of nitrogen fertilizer on dry matter yield and feeding value of Elephant grass (Pennisetum pupureum) and $\mathrm{F}_{1}$ (Pennisetum pupureum hybrids). Nigerian Agricultural Journal, vol. 21, pp. 40-50, 1986.

[37] Lompo, D.J.P. “Gestion de la fertilité des sols dans les systèmes de culture de l'Ouest du Burkina-Faso: Évaluation des effets agronomiques et de la rentabilité économique de trois formules de fumure. Mémoire d'Ingénieur du Développement Rural/Option Agronomie. IDR/UPB. Burkina Faso". 50 p, 2005.

[38] Akoègninou, A., Van Der Burg, W.J. and Van Der Maesen, L.J.G. "Flore analytique du Bénin. Backhuys Publishers, Leiden, Pays Bas". 1034 p, 2006.

[39] Obulbiga, M.F. and Kaboré-Zoungrana, C. "Influence de la fumure azotée et du rythme d'exploitation sur la production de matière sèche et la valeur alimentaire de Andropogon gayanus Kunth au Burkina Faso". Tropicultura, vol. 25, pp. 161-167, 2007.

[40] Diallo, L. "Effet de l'urée et du fumier sur les rendements du maïs". Mémoire d'Ingénieur du Développement Rural/Option Agronomie. IDR/UPB. Burkina Faso. 54p, 2002.

[41] Kebdani, B. and Missat, L. "Etude de l'influence de type de la fertilisation et l'apport de fumure sur la culture de pomme de terre (Solanum tuberosum. L)". Mémoire de Master, Université Abou Bekr Belkaid (Tlemcen), Algérie, 83 p, 2015.

[42] Knoden, D., Lambert, R., Nihoul, P., Stilmant, D., Pochet, P., Crémer, S. and Luxen, P. "Fertilisation raisonnée des prairies". Les Livrets de l'Agriculture $\mathrm{n}^{\circ} 15$. SPW. 45 p, 2007.

[43] Tendonkeng, F., Boukila, B., Pamo, E.T., Mboko, A.V., Matumuini, F.N.E. and Zogang, B.F. "Effet de différents niveaux de fertilisation azotée et du stade phénologique sur la croissance et le rendement de Brachiaria ruziziensis dans 1'Ouest-Cameroun." International Journal of Biological and Chemical Sciences, vol. 3, issue 4, pp. 725735, 2009.

[44] Morot-Gaudry, J-F. "Assimilation de l'azote chez les plantes: aspects physiologique, biochimique et moléculaire". $1^{\mathrm{e}}$ édition, 424 p, 1997. Books.google.com.

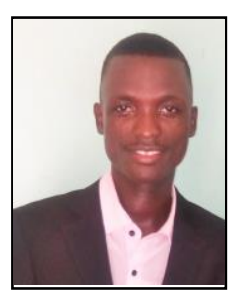

Ezéchiel J-P. A. Mensah was born in 1988 in Dogbo (Benin). He is currently a Ph.D. student in Management of Animal Resources at the Doctoral School of Agricultural Sciences, University of Abomey-Calavi, Benin. Involving in Organic Livestock Farming research, he holds two Masters of Sciences degree in Agricultural Sciences, one Major: Forage Plant Ecophysiology and Improvement from University of Abomey-Calavi in Benin Republic by 2014, after a Bachelor degree in Animal Production Sciences and Technologies in 2011. He is an Agrostologist.

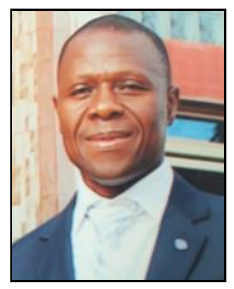

Valentin Kindomihou is $\mathrm{PhD}$ Agronomy, Professor of Agrostology and Animal Production, Laboratory of Applied Ecology, FSA-UAC, Benin. He is member of The Benin Association for Pastoralism (Cotonou-Benin, 1995), The Grassland Society of South Africa (Cape Town - South Africa, 2009), The West African Network for Organic Agriculture Research and Training (Cape-Coast-Ghana, 2009), The International Society for Silicon in Agriculture and Related Disciplines (Stockholm-Sweden, 2014). He was awarded by The Matsumae International Foundation (TokyoJapan, 2006) for his contribution to "Silicon in Agriculture" Research. He is Editor of the Book: "Grasses and Grassland Aspects", IntechOpen, London, UK. 142 pages. ISBN: 9781789849493.

http://dx.doi.org/10.5772/intechopen.77919. 